\title{
PENGARUH KOMPETENSI PROFESIONAL GURU DAN MOTIVASI BELAJAR SISWA TERHADAP PRESTASI BELAJAR SISWA PADA MATA PELAJARAN KEARSIPAN SMK ADMINISTRASI PERKANTORAN DI SMK NEGERI 1 CIAMIS
}

\section{THE IMPACT OF TEACHER'S PROFESSIONAL COMPETENCE AND STUDENT'S MOTIVATION TOWARDS STUDENT'S ACHIEVEMENT IN ARCHIVES SUBJECT OF OFFICE ADMINISTRATION IN VOCATIONAL HIGH SCHOOL 1 CIAMIS}

Jajang Ikbal Herlianto, Suwatno \& Herlina

Email: jajangikbal@student.upi.edu; lina.andiirawan@gmail.com; suwatno@upi.edu

\begin{abstract}
ABSTRAK
Salah satu masalah yang menarik untuk dikaji adalah rendahnya prestasi belajar siswa dalam proses pembelajaran. Pendidikan bertujuan untuk meningkatkan kualitas sumber daya manusia, salah satu usaha untuk meningkatkan kualitas sumber daya manusia yaitu melalui proses pembelajaran di sekolah dengan kualitas sumber daya pendidik yang memadai. Kompetensi guru dan motivasi siswa adalah salah satu faktor yang mempengaruhi tercapainya tujuan pembelajaran dan pendidikan di sekolah. Penelitian ini bertujuan untuk menganalis pengaruh kompetensi profesional guru dan motivasi belajar siswa terhadap prestasi belajar siswa di SMK Negeri 1 Ciamis. Metode penelitian ini menggunakan metode explanatory survey. Responden dalam penelitian ini berjumlah 90 siswa kelas X program keahlian Administrasi Perkantoran di SMK Negeri 1 Ciamis. Teknik analisis data menggunakan regresi ganda dan korelasi product moment serta menggunakan alat analisis berupa software SPSS (Statistic Product and Service Solution) versi 19.0. for windows. Hasil penelitian ini menunjukan bahwa Kompetensi Profesional Guru $\left(\mathrm{X}_{1}\right)$ dan Motivasi belajar Siswa $\left(\mathrm{X}_{2}\right)$ tidak berpengaruh secara simultan dan signifikan terhadap Prestasi Belajar Siswa. Hasil penelitian terhadap 90 responden menunjukan Kompetensi Profesional Guru $\left(\mathrm{X}_{1}\right)$ dan Motivasi belajar Siswa $\left(\mathrm{X}_{2}\right)$ tidak berpengaruh secara simultan dan signifikan terhadap Prestasi Belajar Siswa. Kompetensi Profesional Guru dan Motivasi Belajar Siswa sebesar 5,3\% atau variabel Kompetensi Profesional Guru dan Motivasi Belajar Siswa mempengaruhi Prestasi Belajar Siswa sebesar 5,3\%, sedangkan sisanya sebesar 94,7\% dipengaruhi oleh variabel lain yang tidak dijelaskan dalam penelitian ini.
\end{abstract}

Kata kunci: Kompetensi Profesional Guru, Motivasi Belajar Siswa, Prestasi Belajar 


\begin{abstract}
One of the interesting issues to be studied is the low student achievement of the learning process. Education aims to improve the quality of human resources, one of the efforts to improve the quality of human resources is through the process of learning in schools of course with the quality of adequate educational resources. Teacher competence and student motivation is one of the factors that influence the achievement of learning and education goals in schools. This study aims to analyze the influence of professional competence of teachers and students' learning motivation on student achievement in SMK Negeri 1 Ciamis. The method used in this research is explanatory survey method. Respondents in this study amounted to 90 students of class X of Office Administration skill program at SMK Negeri 1 Ciamis. Data analysis technique using multiple regression and product moment correlation and using analysis tools in the form of software SPSS (Statistic Product and Service Solution) version 19.0. for windows. The results of this study showed that the teacher's professional competence (XI) and Student Learning Motivation (X2) has no effect simultaneously and significantly on Student Learning Achievement. The results of the study of 90 respondents showed Professional Teacher Competence (X1) and Student Learning Motivation (X2) has no effect simultaneously and significantly on Student Learning Achievement. Professional Teacher Competence and Student Motivation of 5.3\% or Professional Competence of Teachers and Student Motivation Affects Student Achievement of 5.3\%, while the rest of $94.7 \%$ is influenced by other variables not described in this study.
\end{abstract}

Keyword: Teachers Professional Competence, Students Learning Motivation, Students Achievement

\title{
PENDAHULUAN
}

Salah satu masalah yang menarik untuk dikaji adalah mengenai rendahnya prestasi belajar siswa dalam proses pembelajaran. Pendidikan bertujuan untuk meningkatkan kualitas sumber daya manusia, salah satu usaha untuk meningkatkan kualitas sumber daya manusia yaitu melalui proses pembelajaran di sekolah tentunya dengan kualitas sumber daya pendidik yang memadai.

Pada era globalisasi seperti sekarang ini berkembangnya ilmu pendidikan dan teknologi yang menuntut kualitas sumber daya manusia yang unggul. Menurut Purwoko (2012) dalam (Suwatno \& Vidi Sukmayadi, 2016) "One of the ways to face the globalization is to prepare the human resource by developing mental and intellectual competency". Salah satu cara untuk menghadapi globalisasi adalah mempersiapkan sumber daya dengan mengembangkan kompetensi mental dan intelektual. "Education in this sense, has a supportive role in achieving both of the competencies" (Suwatno \& Vidi Sukmayadi, 2016). Pendidikan dalam pengertian ini, memiliki peran yang mendukung dalam mencapai kedua kompetensi tersebut.

Fenomena mengenai belum optimalnya prestasi belajar siswa pada salah satu mata pelajaran yang berhubungan dengan aspek kognitif siswa yaitu pada pelajaran Kearsipan dalam kondisi tersebut terlihat dari presentase jumlah peserta didik yang nilainya masih

Manajerial, Vol. 3 No.4 Januari 2018, Hal - 71

http://ejournal.upi.edu/index.php/manajerial/

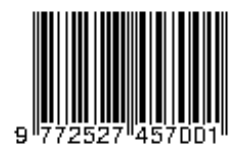


berada di bawah Kriteria Ketuntasan Minimal (KKM). Berdasarkan hal tersebut muncul pertanyaan mengapa prestasi belajar siswa belum optimal? Untuk itu perlu dicari faktorfaktor yang diduga berpengaruh terhadap prestasi belajar siswa.

Seperti pendapat Widodo dan Supriyono (2004, hlm. 198) bahwa "prestasi belajar adalah hasil usaha belajar yang berupa nilai-nilai sebagai ukuran kecakapan dari usaha belajar yang telah dicapai seseorang, prestasi belajar ditunjukan dengan jumlah nilai raport atau nilai tes sumatif'. Maka keberhasilan pendidikan sangat ditentukan oleh kemampuan guru dalam mengelola materi pembelajaran, dalam hal ini mampu meningkatkan produktivitas dan prestasi belajar dan meningkatkan perilaku peserta didik di sekolah.

Kemampuan siswa dalam memahami, menerima pelajaran yang diberikan oleh guru berbeda-beda maka hasil prestasi belajar yang dihasilkan siswa juga berbeda-beda. Proses belajar siswa dipengaruhi oleh beberapa faktor, baik itu faktor internal (dalam diri) maupun eksternal (luar diri).

Salah satu komponen yang penting pada faktor instrumental dalam pembelajaran adalah guru. Guru memegang peranan penting dalam keberhasilan pencapain prestasi belajar siswanya, oleh karena itu guru harus memiliki kompetensi. Salah satu kompetensi yang harus dimiliki oleh guru adalah kompetensi profesional guru. Karena kompetensi profesional guru merupakan kemampuan penguasaan materi pembelajaran secara luas dan mendalam, yang mencakup penguasaan materi kurikulum mata pelajaran disekolah dan substansi keilmuan yang menaungi materinya, serta penguasaan terhadap struktur dan metodologi keilmuan sehingga mampu untuk mengembangkan kualitas yang akan diberikan kepada siswa.

Guru memegang peranan yang sangat strategis terutama dalam membentuk watak bangsa, mengembangkan potensi siswa, dan menentukan keberhasilan pendidikan yang nantinya akan sangat berpengaruh terhadap mutu pendidikan.

Kemudian selain dari kompetensi profesional guru, salah satu yang mempengaruhi prestasi belajar dari segi internal adalah motivasi. Motivasi disini adalah kekuatan yang ada dalam diri seseorang yang ditandai dengan munculnya perasaan untuk melakukan kegiatan tertentu untuk mencapai tujuannya.

Motivasi belajar merupakan pendorong siswa untuk melaksanakan kegiatan belajar dengan sungguh-sungguh sehingga tercapai prestasi yang memuaskan. Sehingga apabila motivasi belajar yang dimiliki siswa tinggi, maka intensitas usaha dan upaya untuk mencapai tujuan yang diharapkan akan semakin tinggi sehingga memperoleh prestasi belajar yang tinggi. Sebaliknya apabila motivasi belajar yang dimiliki oleh siswa rendah, maka prestasi belajar yang diperolehnya akan rendah.

Berdasarkan hal tersebut, mengingat pentingnya prestasi belajar siswa yang berdampak langsung terhadap mutu pendidikan di Indonesia, maka masalah prestasi belajar siswa ini merupakan aspek penting dalam pendidikan untuk diteliti. Faktor kompetensi profesional guru dan motivasi belajar siswa merupakan dua faktor yang menarik untuk dikaji lebih dalam yang kaitannya dengan prestasi belajar siswa.

Manajerial, Vol. 3 No.4 Januari 2018, Hal - 72

http://ejournal.upi.edu/index.php/manajerial/

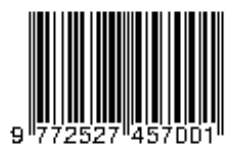




\section{KAJIAN PUSTAKA \\ Prestasi Belajar Siswa}

Menurut Abin Syamsudin (2005, hlm. 7) menyatakan bahwa: Prestasi belajar merupakan indikator dari perubahan dan perkembangan perilaku dalam term-term pengetahuan (penalaran) sikap (penghayatan) dan keterampilan (pengalaman). Perubahan dan perkembangan ini mempunyai arah yang positif dan negatif dan kualifikasinya pun akan terbagi-bagi, seperti tinggi, sedang, rendah atau berhasil, tidak berhasil, dan lulus tidak lulus. Kriteria tersebut akan tergantung pada diri siswa itu sendiri. Muhibbin Syah (2010, hlm. 141) mengatakan bahwa "Prestasi belajar merupakan hasil interaksi dari sebagian faktor yang mempengaruhi proses belajar secara keseluruhan”.

Ghullam Hamdu dan Lisa Agustina (2011, hlm. 83) mengatakan bahwa "Prestasi belajar adalah suatu bukti keberhasilan belajar atau kemampuan seseorang siswa dalam melakukan kegiatan belajar sesuai dengan bobot yang dicapainya".

Zuhaira Laily Kusuma dan Subkhan (2015, hlm. 165) menyatakan bahwa prestasi belajar adalah penguasaan pengetahuan atau keterampilanyang dikembangkan oleh mata pelajaran,lazimnya ditunjukkan dengan nilai tes atauangka yang diberikan oleh guru. Nilai atauangka yang diberikan guru tersebut dicapaisiswa dalam proses pembelajaran di sekolahyang dapat diwujudkan dalam nilai rapor.

Pendapat lain datang dari Izuddin Syarif (2012, hlm. 4) bahwa yang dimaksud dengan prestasi belajar adalah suatu usaha atau kegiatan anak untuk menguasai bahanbahan pelajaran yang diberikan guru di sekolah.

Sedangkan menurut Umami \& Roesminingsih (2014, hlm. 83) bentuk prestasi belajar yang selalu didapat oleh para siswa disekolah adalah nilai-nilai dalam bentuk angka maupun huruf. Nilai-nilai tersebut diberikan oleh guru sebagai salah satu bentuk penguatan dan penilaian hasil belajar yang telah dicapai oleh siswa".

\section{Kompetensi Profesional Guru}

Dalam melaksanakan tugasnya guru sebagai seorang pengajar tidak hanya dituntut untuk menguasai materi yang akan disampaikan kepada siswa, namun guru juga harus mampu memahaminya secara luas dan mendalam. Oleh karena itu guru harus memiliki kompetensi dalam mengajar sehari-hari. Setidaknya seorang guru harus mampu dan memiliki kompetensi dasar serta pemahaman menganai keilmuan di bidang yang dipilihnya.

Peraturan Pemerintah Nomor 19 Tahun 2015 tentang Standar Nasional Pendidikan Pasal 28 ayat 1 menegaskan bahwa "Pendidik harus memiliki kualifikasi akademik, dan kompetensi sebagai agen pembelajaran, sehat jasmani dan rohani, serta memiliki kemampuan untuk mewujudkan tujuan pendidikan nasional".

Dalam Undang-Undang No. 14 Tahun 2005 tentang Guru dan Dosen yang dimaksud dengan kompetensi profesional adalah "kemampuan penguasaan materi secara luas dan mendalam".

Menurut Peraturan Pemerintah No. 74 tentang Guru mengenai kompetensi profesional guru dijelaskan bahwa: Kompetensi profesional merupakan kemampuan guru dalam menguasai pengetahuan bidang ilmu pengetahuan teknologi atau seni dan budaya yang diampunya sekurang-kurangnya meliputi penguasaan: materi pelajaran secara luas 
dan mendalam sesuai standar isi program satuan pendidikan mata pelajaran atau kelompok mata pelajaran yang diampu dan konsep, metode disiplin keilmuan, teknologi atau seni yang relevan, yang secara konseptual menaungi atau koheren dengan program satuan pendidikan, mata pelajaran, atau kelompok mata pelajaran yang di ampu.

Senada dengan pendapat tersebut, menurut Yamin dan Maisah (2010, hlm. 11) menyatakan bahwa: Kompetensi profesional merupakan kemampuan penguasaan materi pembelajaran secara luas dan mendalam, yang mencakup penguasaan materi kurikulum mata pelajaran disekolah dan substansi keilmuan yang menaungi materinya, serta penguasaan terhadap struktur dan metodologi keilmuan.

Pendapat lain datang dari Buchari Alma (2008, hlm. 142) mengemukakan bahwa Kompetensi Profesional adalah kemampuan penguasaan materi pelajaran secara luas dan mendalam, serta metode dan teknik mengajar yang sesuai yang dipahami oleh murid, mudah ditangkap, tidak menimbulkan kesulitan dan keraguan.

Menurut Maulinar (2015, hlm. 145) Kompetensi profesional merupakan kemampuan Guru dalam menguasai pengetahuan bidang ilmu pengetahuan, teknologi, dan/atau seni dan budaya yang diampunya yang sekurang-kurangnya meliputi penguasaan: a) materi pelajaran secara luas dan mendalam sesuai dengan standar isi program satuan pendidikan, mata pelajaran, dan/atau kelompok mata pelajaran yang akan diampu dan b) konsep dan metode disiplin keilmuan, teknologi, atau seni yang relevan, yang secara konseptual menaungi atau koheren dengan program satuan pendidikan, mata pelajaran, dan/atau kelompok mata pelajaran yang akan diampu.

Menurut Syahrudin, dkk (2013, hlm. 143-148) "Kompetensi profesional dapat didefinisikan sebagai kemampuan guru untuk menguasai mata pelajaran mereka secara mendalam dan cara untuk tepat menyampaikannya kepada siswa, kompetensi yang harus dikuasai guru dalam kaitannya dengan pelaksanaan tugas utamanya mengajar, kemampuan yang berhubungan erat dengan penyesuaian tugas-tugas keguruan. Tugas keguruan yang dimaskud yaitu segala sesuatu yang harus dipersiapkan oleh seorang guru terutama sebagai pengajar.

Pandangan lain datang dari Adnan Hakim (2015, hlm. 3) menyatakan bahwa: Competencies related to the skills of teachers in the learning process are included in the category of professional competence. Professional competence is the mastery of learning materials is broad and deep, covering mastery of curriculum content and substance of scientific subjects philosophically, the ability of dealing with the adjustment tasks and competence of lecturers is very important because it directly relates to the performance shown.

Sedangkan menurut Jafaruddin (2015, hlm. 63) Guru sebagai pendidik profesional mempunyai citra yang baik di masyarakat "guru sebagai pendidik profesional mempunyai citra yang baik dimasyarakat apabila dapat menunjukkan kepada masyarakat bahwa ia layak menjadi panutan atau teladan bagi masyarakat sekelilingnya".

\section{Motivasi Belajar Siswa}

Motovasi berangkat dari kata motif. Menurut Sardiman (2011, hlm. 72) "motif diartikan sebagai daya upaya yang mendorong seseorang untuk melaksanakan sesuatu". Adapun menurut Faturrohman dan Sutikno (2009, hlm. 19) "motif diartikan sebagai daya 
penggerak dari dalam dan di dalam diri seseorang untuk melakukan aktivitas-aktivitas tertentu demi mencapai suatu tujuan". Daya penggerak tersebut akan menjadi aktif ketika kebutuhan untuk mencapai tujuan sangat dirasakan atau mendesak. Motif yang telah menjadi aktif inilah yang disebut motivasi.

Berkaitan dengan kegiatan belajar Sardiman (2011, hlm. 75) mengungkapkan motivasi sebagai berikut: Dalam kegiatan belajar motivasi dapat diartikan sebagai keseluruhan daya penggerak di dalam diri siswa yang menimbulkan kegiatan belajar, yang menjamin kelangsungan dari kegiatan belajar, dan memberikan arah pada kegiatan belajar, sehingga tujuan yang dikehendaki oleh subjek belajar itu dapat tercapai.

Menurut Budi Marwan (2006, hlm. 37) menyatakan bahwa Motivasi adalah suatu faktor yang mendorong seseorang untuk melakukan suatu aktivitastertentu, oleh karena itu motivasi sering kali diartikan pula sebagai faktor pendorong perilaku seseorang. Setiap aktivitas yang dilakukan oleh seseorang pasti memiliki suatu faktor yang mendorong aktivitas tersebut.

Alimuddin S. Miru (2009, hlm. 3) mengemukanan "Motivasi belajar merupakan faktor penentu dan berfungsi menimbulkan, mendasari dan mengarahkan perbuatan belajar.

Nur Rofiah Darojah dan Hady Siti Hadijah (2016, hlm. 115-125)menyatakan bahwa Motivasi dikonseptualisasikan sebagai keadaan internal yang membangkitkan, mengarahkan, dan memelihara perilaku yang berorientasi pada tujuan.

Pendapat lain datang dari Riyadul Inayah, dkk (2013, hlm. 4) Motivasi belajar siswa adalah merupakan faktor psikis yang bersifat nonintelektual. Peranannya yang khas adalah dalam hal penumbuhan gairah, merasa senang dan semangat dalam belajar.

Sedangkan menurut Amelia Pramitasari dan Yeniar Indriana (2011, hlm. 94)mengatakan bahwa motivasi belajar merupakan daya penggerak psikis dari dalam diri seseorang untuk dapat melakukan kegiatan belajar dan menambah keterampilan serta pengalaman. Motivasi mendorong dan mengarahkan minat belajar untuk mencapai suatu tujuan. Siswa akan bersungguh-sungguh belajar karena termotivasi mencari prestasi, mendapatkan kedudukan dalam jabatan, menjadi politikus, dan memecahkan masalah.

\section{METODOLOGI}

Penelitian ini menggunakan metode Explanatory Survey. Metode ini dianggap tepat karena penelitian ini dilakukan untuk mengumpulkan informasi faktual melalui penggunaan kuesioner. Responden adalah siswa SMK Negeri 1 Ciamis, Provinsi Jawa Barat, Indonesia sebanyak 90 orang.

Instrumen pengumpulan data berupa angket kuisioner. Kuesioner untuk mengukur persepsi responden mengenai kompetensi profesional guru yang dijabarkan dari lima indikator yaitu yaitu Menguasai materi, struktur, konsep, dan pola pikir keilmuan yang mendukung mata pelajaran yang diampu, Menguasai standar kompetensi dan kompetensi dasar/mata pelajaran bidang pengembangan yang diampu, Mengembangkan materi pelajaran yang diampu secara kreatif, Mengembangkan keprofesionalan secara berkelanjutan dengan melakukan tindakan reflaktif, dan Memanfaatkan teknologi informasi dan komunikasi untuk berkomunikasi dan mengembangkan diri. Kelima 
indikator tersebut diuraikan menjadi 16 pernyataan yang dijadikan pernyataan kuesioner untuk dijadikan ukuran tentang variabel Kompetensi Profesional Guru berdasarkan perhitungan dari 90 responden.. Dan kuesioner untuk mengukur persepsi responden mengenai motivasi belajar siswa yang dijabarkan dari 3 indikator yaitu Penggunaan Waktu, Pengorbanan, dan Aspirasi Yang Ingin Didapat. Ketiga indikator tersebut diuraikan menjadi 15 pernyataan yang dijadikan pernyataan kuesioner untuk dijadikan ukuran tentang variabel Motivasi Belajar Siswa berdasarkan perhitungan dari 90 responden.

Statistik deskriptif menggunakan skor rata-rata yang digunakan untuk memperoleh gambaran tingkat persepsi responden mengenai kompetensi profesional guru. Statistik inferensial menggunakan analisis regresi ganda dan korelasi product moment yang digunakan untuk menguji hipotesis. Berdasarkan pendahuluan dan tinjauan pustaka tujuan penelitian ini untuk mengetahui pengaruh kompetensi profesional guru dan motivasi belajar siswa terhadap prestasi belajar siswa maka hipotesis pada penelitian dapat dikembangkan sebagai berikut:

Hipotesis 1: $\quad$ Terdapat pengaruh positif dan signifikan antara kompetensi profesional guru terhadap prestasi belajar siswa

Hipotesis 2: $\quad$ Terdapat pengaruh positif dan signifikan antara motivasi belajar siswa terhadap prestasi belajar siswa

Hipotesis 3: Terdapat pengaruh positif dan signifikan antara kompetensi profesional guru dan motivasi belajar siswa terhadap prestasi belajar siswa

\section{HASIL PENELITIAN DAN PEMBAHASAN}

\section{Kompetensi Profesional Guru}

Skor rata-rata mencapai 4,13. Apabila disesuaikan dengan skala penafsiran pada tabel skala likert terdapat pada rentang 3,8 - 5,1 maka dikategorikan tinggi. Disajikan dalam bentuk tabel sebagai berikut:

\section{Tabel 1}

\section{Skor rata-rata Variabel X1 Kompetensi Profesional Guru}

\begin{tabular}{|c|c|c|c|}
\hline Indikator & Item & Rata-rata & Penafsiran \\
\hline $\begin{array}{l}\text { Menguasai materi, } \\
\text { dan ptruktur, konsep, } \\
\text { mendukung mikir keilmuan yang } \\
\text { diampu }\end{array}$ & $1-2$ & 4,63 & Sedang \\
\hline $\begin{array}{l}\text { Menguasai standar kompetensi dan } \\
\text { kompetensi dasar/mata pelajaran } \\
\text { bidang pengembangan yang diampu }\end{array}$ & $3-5$ & 3,30 & Sedang \\
\hline $\begin{array}{l}\text { Mengembangkan materi pelajaran } \\
\text { yang diampu secara kreatif }\end{array}$ & $6-10$ & 3,56 & Sedang \\
\hline $\begin{array}{l}\text { Mengembangkan keprofesionalan } \\
\text { secara berkelanjutan dengan } \\
\text { melakukan tindakan reflaktif }\end{array}$ & $11-12$ & 4,63 & Tinggi \\
\hline $\begin{array}{l}\text { Memanfaatkan teknologi informasi } \\
\text { dan komunikasi untuk berkomunikasi }\end{array}$ & $13-16$ & 4,52 & Tinggi \\
\hline
\end{tabular}


dan mengembangkan diri

Rata-rata

4,13

Tinggi

Skor tertinggi kompetensi profesional guru berada pada Menguasai materi, struktur, konsep, dan pola pikir keilmuan yang mendukung mata pelajaran yang diampu. Hal ini memiliki makna bahwa guru mampu menguasai materi yang dibutuhkan oleh siswa serta mampu menguasai konsep, struktur dan pola pikir keilmuan sebagai pendukung dalam mata pelajaran yang diampunya. Skor terendah indikator kompetensi profesional guru yaitu Menguasai standar kompetensi dan kompetensi dasar/mata pelajaran bidang pengembangan yang diampu. Disimpulkan presepsi kompetensi profesional guru di SMK Negeri 1 Ciamis secara keseluruhan dikategorikan Tinggi.

\section{Motivasi Belajar Siswa}

Skor rata-rata mencapai 3,72. Apabila disesuaikan dengan skala penafsiran pada tabel skala likert terdapat pada rentang 2,4 - 3,7 maka dikategorikan Sedang. Disajikan dalam bentuk tabel sebagai berikut:

Tabel 2

Skor rata-rata Variabel X2 Motivasi Belajar Siswa

\begin{tabular}{lccc}
\hline \multicolumn{1}{c}{ Indikator } & Item & Rata-rata & Penafsiran \\
\hline Penggunaan Waktu & $1-3$ & 3,81 & Tinggi \\
\hline Pengorbanan & $4-11$ & 3,67 & Sedang \\
\hline Aspirasi Yang Ingin Dicapai & $12-15$ & 3,69 & Sedang \\
\hline \multicolumn{1}{r}{ Rata-rata } & & $\mathbf{3 , 7 2}$ & Sedang \\
\hline
\end{tabular}

Skor tertinggi motivasi belajar siswa berada pada Penggunaan Waktu. Hal ini memiliki makna bahwa siswa sudah bisa memotivasi diri melalui penggunaan waktu. Skor terendah indikator motivasi belajar siswwa yaitu Pengorbanan. Disimpulkan presepsi motivasi belajar siswa di SMK Negeri 1 Ciamis secara keseluruhan dikategorikan Sedang.

\section{Prestasi Belajar Siswa}

Prestasi belajar siswa pada penelitian ini diukur melalui nilai ujian akhir semester genap siswa pada tahun ajaran 2017/2018 pada mata pelajaran kearsipan. Nilai rata-rata siswa pada Mata Pelajaran Kearsipan hanya mencapai nilai 81 dengan nilai maksimum yang diperoleh siswa adalah 98 dan nilai minimum adalah 71 jika dihubungkan dengan penafsiran skor deskriptif nilai raport pada tabel sebelumnya maka berada pada rentang 81 - 89 yang termasuk pada kategori Sedang. Dengan demikian bahwa rata-rata tingkat prestasi belajar siswa di SMK Negeri 1 Ciamis tergolong pada kategori Sedang. 


\section{HIPOTESIS}

\section{Hipotesis 1: Pengaruh Kompetensi Profesional Guru Terhadap Prestasi Belajar Siswa}

Berdasarkan hasil analisis nilai $t_{\text {hitung }}=2,092$. Sedangakan untuk nmendapatkan $t_{\text {tabel }}$ dapat dicari pada $t_{\text {tabel }}$ dengan cara $t(\alpha / 2 ; n-k-1)=(0,05 / 2 ; 90-2-1)$ dengan demikian diperoleh $t_{\text {tabel }}$ sebesar 1,98761.

Untuk melakukan pengujian hipotesis 1 penulis membandingkan nilai uji thitung terhadap nilai $t_{\text {tabel}}$. Berdasarkan dari pengelolahan data tersebut maka diperoleh $t_{\text {hitung }}>$ $t_{\text {tabel }}$ dengan nilai $2,092>1,98761$. Karena nilai $t_{\text {hitung }}$ lebih besar dari pada $t_{\text {tabel }}$ sehingga dapat disimpulkan $\mathrm{H}_{0}$ ditolak dan $\mathrm{H}_{1}$ diterima dengan demikian "Ada pengaruh positif kompetensi profesional guru terhadap prestasi belajar siswa pada mata pelajaran kearsipan SMK Administrasi Perkantoran di SMK Negeri 1 Ciamis".

Dari hasil penrhitungan SPSS didapat nilai koefisien korelasi (r) sebesar 0,063. Hal ini menunjukkan bahwa adanya pengaruh dari Variabel Kompetensi Profesional Guru $\left(\mathrm{X}_{1}\right)$ terhadap Variabel Prestasi Belajar Siswa (Y). Hasil interpretasi menunjukan bahwa hubungan yang terjadi antara variabel X1 dan Y tergolong Sangat Rendah, karena koefisien korelasi $(r)$ sebesar 0,063 berada pada rentang skor antara 0,00 - 0,199. Sedangkan tanda ' $* *$ ' menujukan bahwa semakin tinggi kompetensi profesional guru, maka akan semakin tinggi prestasi belajar siswa dan begitupun sebaliknya.

\section{Hipotesis 2: Pengaruh Motivasi Belajar Siswa Terhadap Prestasi Belajar Siswa}

Berdasarkan hasil analisis diatas nilai $t_{\text {hitung }}=-2,120$. Sedangakan untuk mendapatkan $t_{\text {tabel }}$ dapat dicari pada $t_{\text {tabel }}$ dengan cara $t(\alpha / 2 ; n-k-1)=(0,05 / 2 ; 90-2-1)$ dengan demikian diperoleh $\mathrm{t}_{\text {tabel }}$ sebesar 1,98761.

Untuk melakukan pengujian hipotesis 2 penulis membandingkan nilai uji $t_{\text {hitung }}$ terhadap nilai tabel. Berdasarkan dari pengelolahan data tersebut maka diperoleh $t_{\text {hitung }}>$ $t_{\text {tabel }}$ dengan nilai $-2,120<1,98761$. Karena nilai $t_{\text {hitung }}$ lebih kecil dari pada $t_{\text {tabel }}$ sehingga dapat disimpulkan $\mathrm{H}_{0}$ diterima dan $\mathrm{H}_{1}$ ditolak dengan demikian "Tidak ada pengaruh positif motivasi belajar siswa terhadap prestasi belajar siswa pada mata pelajaran kearsipan SMK Administrasi Perkantoran di SMK Negeri 1 Ciamis".

Dari hasil perhitungan SPSS didapat nilai koefisien korelasi (r) sebesar -0,072. Koefisien korelasi tersebut menunjukkan bahwa sangat rendah atau bahkan hampir tidak ada pengaruh dari Variabel Motivasi Belajar Siswa $\left(\mathrm{X}_{2}\right)$ terhadap Variabel Prestasi Belajar Siswa (Y) karena koefisien korelasi $(r)$ sebesar -0,072 dan tidak terdapat pada rentang skor interpretasi diatas. Tanda negatif (-) menunjukan hubungan yang berlawanan, jika motivasi belajar siswa tinggi maka prestasi belajar siswa rendah dan sebaliknya.

\section{Hipotesis 3: Pengaruh Kompetensi Profesional Guru Dan Motivasi Belajar Siswa Terhadap Prestasi Belajar Siswa}

Teknik analisis data yang digunakan untuk mengetahui pengaruh kompetensi profesional guru dan morivasi belajar siswa terhadap prestasi belajar siswa dengan menggunakan regresi ganda (multiple regression). Berdasarkan hasil analisis diatas nilai $f_{\text {hitung }}=2,430$. Sedangakan untuk mendapatkan $f_{\text {tabel }}$ dapat dicari pada $f_{\text {tabel }}$ dengan cara $f(k$ ; $\mathrm{n}-\mathrm{k})=(2 ; 90-2)$ dengan demikian diperoleh $\mathrm{f}_{\text {tabel }}$ sebesar 3,10. Berdasarkan dari pengelolahan data tersebut maka diperoleh $\mathrm{f}_{\text {hitung }}<\mathrm{f}_{\text {tabel }}$ dengan nilai 2,430<3,10. Karena nilai $\mathrm{f}_{\text {hitung }}<\mathrm{f}_{\text {tabel }}$ dapat ditarik kesimpulan bahwa $\mathrm{H}_{0}$ diterima dan $\mathrm{H}_{1}$ ditolak. Dengan 
demikian, "Kompetensi profesional guru dan motivasi belajar siswa tidak berhubungan simultan (bersama) dan signifikan terhadap prestasi belajar siswa pada mata pelajaran kearsipan SMK Administrasi Perkantoran di SMK Negeri 1 Ciamis".

Dari hasil di atas, dapat dibuat persamaan regresi sebagai berikut:

$$
\mathrm{Y}=\mathrm{a}+\mathrm{b}_{1} \mathrm{X}_{1}+\mathrm{b}_{2} \mathrm{X}_{2}
$$

Angka-angka ini dapat diartikan sebagai berikut:

$\mathrm{a}=$ angka konstan dari unstandarized coefficients sebesar 77,128. Artinya jika tidak ada Kompetensi Profesional Guru (X1) dan Motivasi Belajar Siswa (X2), maka nilai konsisten Prestasi Belajar Siswa (Y) adalah sebesar 77,128.

$\mathrm{b}_{1}=$ angka koefisien regresi. Nilainya sebesar 0,301. Angka ini mengandung arti bahwa setiap penambahan 1\% tingkat Kompetensi Profesional Guru (X1), maka Prestasi Belajar Siswa (Y) akan meningkat sebesar 0,301.

$\mathrm{b}_{2}=$ angka koefisien regresi. Nilainya sebesar -0,276. Angka ini mengandung arti bahwa setiap penambahan 1\% tingkat Motivasi Belajar Siswa (X2), maka Prestasi Belajar Siswa (Y) akan menurun sebesar -0,276.

Karena nilai koefisien regresi $b_{1}$ besifat $(+)$ positif, maka dengan demikian dapat dikatakan bahwa Kompetensi Profesional Guru (X1) berpengaruh positif terhadap Prestasi Belajar Siswa (Y). Sebaliknya karena nilai koefisien regresi $b_{2}$ besifat (-) negatif, maka dengan demikian dapat dikatakan bahwa Motivasi Belajar Siswa (X2) berpengaruh negatif terhadap Prestasi Belajar Siswa (Y). Sehingga persamaan regresinya adalah Y $=77,128+$ $0,301 \mathrm{X}_{1}+(-0,276) \mathrm{X}_{2}$

Berdasarkan hasil perhtungan analisis dengan SPSS koefisien regresi, diperoleh data sebagai berikut:

1) Korelasi $X_{1} Y=0,063$

2) Korelasi $X_{2} Y=-0,072$

3) Korelasi $\mathrm{r}_{\mathrm{X} 1 \mathrm{X} 2 \mathrm{Y}}=0,826$

Karena nilai koefisien regresi $\mathrm{X}_{1}$ besifat (+) positif, maka dengan demikian dapat dikatakan bahwa Kompetensi Profesional Guru (X1) berpengaruh positif terhadap Prestasi Belajar Siswa, hal tersebut bermakna jika kompetensi profesional guru naik maka prestasi belajar siswa akan naik. Sebaliknya, karena Motivasi Belajar Siswa (X2) bersifat (-) negatif, dengan demikian dapat dikatakan bahwa Motivasi Belajar Siswa (X2) berpengaruh negatif terhadap Prestasi Belajar Siswa, hal tersebut bermakna jika Motivasi Belajar Siswa naik maka prestasi belajar siswa akan turun.

Koefisien determinasi sebesar 0,053 berarti bahwa variasi Prestasi Belajar Siswa dapat dijelaskan oleh variasi Kompetensi Profesional Guru dan Motivasi Belajar Siswa sebesar 5,3\% atau variabel Kompetensi Profesional Guru dan Motivasi Belajar Siswa mempengaruhi Prestasi Belajar Siswa sebesar 5,3\%, sedangkan sisanya sebesar 94,7\% dipengaruhi oleh variabel lain yang tidak dijelaskan dalam penelitian ini. 


\section{KESIMPULAN}

1. Tingkat kompetensi profesional guru pada mata pelajaran kearsipan di SMK Negeri 1 Ciamis berada pada kategori tingkat Tinggi.

2. Tingkat motivasi belajar siswa kelas $X$ program keahlian Administrasi Perkantoran pada mata pelajaran kearsipan administrasi perkantoran di SMK Negeri 1 Ciamis berada pada kategori tingkat Sedang.

3. Tingkat prestasi belajar siswa kelas X program keahlian Administrasi Perkantoran pada mata pelajaran kearsipan administrasi perkantoran di SMK Negeri 1 Ciamis berada pada kategori tingkat Sedang.

4. Kompetensi profesional guru berpengaruh positif terhadap prestasi belajar siswa kelas X program keahlian Administrasi Perkantoran pada mata pelajaran kearsipan administrasi perkantoran di SMK Negeri 1 Ciamis. Artinya, semakin tinggi kompetensi profesional guru maka semakin tinggi pula prestasi belajar siswa.

5. Motivasi belajar siswa tidak berpengaruh positif terhadap prestasi belajar siswa kelas X program keahlian Administrasi Perkantoran pada mata pelajaran kearsipan administrasi perkantoran di SMK Negeri 1 Ciamis. Tanda negatif (-) menunjukan hubungan yang berlawanan. Artinya, jika motivasi belajar siswa tinggi maka prestasi belajar siswa rendah dan sebaliknya.

6. Kompetensi profesional guru dan motivasi belajar siswa tidak sama-sama berpengaruh positif terhadap prestasi belajar siswa kelas $\mathrm{X}$ program keahlian Administrasi Perkantoran pada mata pelajaran kearsipan administrasi perkantoran di SMK Negeri 1 Ciamis. Sehingga dengan demikian dapat dikatakan bahwa Kompetensi Profesional Guru $\left(\mathrm{X}_{1}\right)$ dan Motivasi belajar Siswa $\left(\mathrm{X}_{2}\right)$ tidak berpengaruh secara simultan dan signifikan terhadap Prestasi Belajar Siswa.

\section{DAFTAR PUSTAKA}

Alma, B. (2008). Guru Profesional. Bandung: Alfabeta.

Darojah, N. R., \& Hadijah, H. S. (2016). An Analysis of The Influence of Personal Competence of Teachers with Motivation to Learn as An Intervening Variable on Achievement of Administrative Office Student Grade X. Jurnal pendidikan manajemen perkantoran Volume 1, nomor 1, Agustus 2016, 115-125.

Faturrohman, \& Sutikno. (2009). Strategi Belajar Mengajar Melalui Penerapan Konsep Umum \& Islami. Bandung: Refika Aditama.

Hakim, A. (2015). Contribution of Competence Teacher (Pedagogical, Personality, Professional Competence and Social) On the Performance of Learning. The International Journal Of Engineering And Science (IJES) Volume 4 Issue 2 , 3.

Hamdu, G., \& Agustina, L. (2011). Pengaruh Motivasi Belajar Siswa Terhadap Pestasi Belajar IPA Di Sekolah Dasar (Studi Kasus terhadap Siswa Kelas IV SDN Tarumanagara Kecamatan Tawang Kota Tasikmalaya). Jurnal Penelitian Pendidikan Vol. 12 No. 1, April 2011, 83. 
Jafaruddin. (2015). Kompetensi Profesional Guru Dalam Meningkatkan Prestasi Belajar Siswa SMAN 1 Kuta Cot Glie Kabupaten Aceh Besar. Intelektualita Volume 1 No. 3,63 .

Kusuma, Z. L., \& Subkhan. (2015). Pengaruh Motivasi Belajar Dan Kedisiplinan Belajar Terhadap Prestasi Belajar Mata Pelajaran Akuntansi Siswa Kelas XI IPS SMA N 3 Pati Tahun Pelajaran 2013/2014. Economic Education Analysis Journal Vol. 4 No. 1,165

Maulinar. (2015). Kompetensi Guru Dalam Memotivasi Siswa Dalam proses Pembelajaran Pada SMP Negeri 1 Syamtalira Bayu Kabupaten Aceh Utara. Jurnal Administrasi Pendidikan Pascasarjana Unsiyah Vol 3 No 1, 142-157.

Miru, A. S. (2009). Hubungan Antara Motivasi Belajar Terhadap Prestasi Belajar Mata Diklat Instalasi Listrik Siswa SMK Negeri 3 Makassar. Jurnal MEDTEK, Volume 1, Nomor 1, 3.

Ridaul Inayah, d. (2013). Pengaruh Kompetensi Guru, Motivasi Belajar siswa dan Fasilitas Belajar Terhadap Prestasi Belajar Mata Pelajaran Ekonomi Pada Siswa Kelas XI IPS SMA Negeri 1 Lasem Jawa Tengah Tahun Pelajaran 2011/2012. Jurnal Pendidikan Insan Mandiri Vol. 1 No. $1,1$.

Roesminingsih, D. R. (2014). Pengaruh Kompetensi Pedagogik Dan Motivasi Kerja Guru Terhadap Prestasi Belajar Siswa Dalam Ujian Nasional (UN) Di SMA Negeri Se Kota Mojokerto.Jurnal Inspirasi Manajemen Pendidikan, Vol. 3 No. 3, 81-88.

Pramitasari, A., \& Indriana, Y. (2011). Hubungan Antara Persepsi Terhadap Metode Pembelajaran Kontekstual Dengan Motivasi Belajar Biologi Siswa Kelas XI IPA SMAN 1 Pangkalan Kerinci, Riau. Jurnal Psikologi Undip Vol. 9, No.1, 94.

Purwanto, N. (2007). Psikologi Pendidikan. Bandung: PT Remaja Rosdakarya.

Sardiman. (2011). Interaksi dan Motivasi Belajar Mengajar. Jakarta: Raja Grafindo Persada.

Suwatno, dkk. (2012). Implementasi Proses Pembelajaran dalam Mencapai Kompetensi Guru Bidang Keahlian Manajemen Perkantoran. Jurnal Manajerial dan Sistem Informasi. Vol. 10 No. 20. ISSN 1412-6613.

Suwatno and Vidi Sukmayadi. (2016). Indonesian as A Foreign Language: Students' Intercultural Communication Learning Competence and Experiences. MAN IN INDIA. International Journal of Anthropology. Vol. 96, No. 8. ISSN 0025-1569.

Syah, M. (2010). Psikologi Pendidikan dengan Pendekatan Baru. Bandung: PT. Remaja Rosdakarya.

Syahrudin, E. A. (2013). The Role of Teachers ${ }^{e e}$ Professional Competence in Implementing School Based Management: Study Analisys at Secondary School in Pare-Pare City of South Sulawesi Province-Indonesia. International Journal of Evaluation and Research in Education (IJERE), 2 (3), 143-148.

Syamsudin, A. M. (2005). Psikologi Kependidikan. Bandung: Remaja Rosdakarya.

Syarif, I. (2012). Pengaruh Model Blended Learning Terhadap Motivasi Dan Prestasi Belajar Siswa SMK. Jurnal Pendidikan Vokasi, Vol 2, Nomor 2, 4.

Manajerial, Vol. 3 No.4 Januari 2018, Hal - 81

http://ejournal.upi.edu/index.php/manajerial/

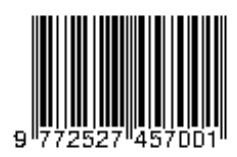


Warman, B. (2006). The Effect of Teachers' Professional Competence and Learning Motivation on Accounting Students' Learning Outcomes at Vocational High School I of Jambi. Jurnal Pendidikan dan Keguruan Vol. 1 No. 1, 2016, artikel 3, 37.

Widodo, A. A., \& Supriyono. (2004). Psikologi Belajar. Jakarta: PT Rineka.

Yamin, \& Maisah. (2010). Standar Kinerja Guru. Jakarta: Gaung Persada. 